\title{
Response of the dominant rodent species to close-to- nature logging practices in a temperate mixed forest
}

\author{
P. Lešo, A. Lešová, R. Kropil, P. Kaňuch
}

Lešo P., Lešová A., Kropil R., Kaňuch P., 2016. Response of the dominant rodent species to close-to-nature logging practices in a temperate mixed forest. Ann. For. Res. 59(1): 259-268.

Abstract. The paper aims to answer the question whether differences exist in microhabitat preferences of the yellow-necked mouse and the bank vole between the natural forest and close-to-nature managed forest in the phase of stand regeneration. The two species were live-trapped during two periods in 2006 and 2007 on a square trapping grid established in a managed forest and a natural one. Ten microhabitat variables of each trapping point were measured to analyse their influence on the spatial distribution of the two species. At trapping points, the number of capture records for each species as a dependent variable was modelled using Generalised Linear Models. The herbal cover and a distance to the nearest woody debris were the most important measured microhabitat variables which affect the spatial distribution of both species. In the natural forest, the number of captures in both species increased significantly $(p<0.05)$ with a decreasing number of trees, increasing undergrowth coverage and decreasing distance to the nearest woody debris. In the managed forest, an increasing distance to the nearest tree and increasing herbal cover had a negative effect on the yellow-necked mouse occurrence $(p<0.001)$, while in contrast, the increase in values of the same variables increased frequency of occurrence of the bank vole ( $\mathrm{p}$ $<0.001)$. Moreover, the bank vole was more frequent in the presence of woody debris $(p<0.002)$. The study demonstrated clearly that these species modify their spatial activity depending on the management of the woodland.

Keywords habitat selection, woodland, fir-beech forest, Apodemus flavicollis, Clethrionomys glareolus, Carpathians Mountains

Author. Peter Lešo (leso@tuzvo.sk) - Department of Forest Protection and Game Management, Faculty of Forestry, Technical University in Zvolen, T. G. Masaryka 20, SK-96053 Zvolen, Slovakia; Andrea Lešová - State Nature Conservancy of the Slovak Republic, Tajovského 28B, SK-974 09 Banská Bystrica, Slovakia; Rudolf Kropil - Department of Forest Protection and Game Management, Faculty of Forestry, Technical University in Zvolen, T. G. Masaryka 20, SK-96053 Zvolen, Slovakia; Peter Kaňuch - Institute of Forest Ecology, Slovak Academy of Sciences, Štúrova 2, SK-96053 Zvolen, Slovakia.

Manuscript received January 01, 2015; revised May 09, 2016; accepted May 16, 2016; online first June 13, 2016. 


\section{Introduction}

Forest management influences the composition and structure of animal assemblages, mainly by changing their habitats (Fuller \& Warren 1991, Baker \& Lacki 1997, Ecke et al. 2002, Perry \& Thill 2013). Depending on the type of the silviculture system applied, changes of the habitat vary from mild structural changes in trees (age, density, plant species composition and diversity) through stand fragmentation to a complete deforestation (clearcuts). Apart from the total habitat destruction, it is especially fragmentation of forests that radically changes the ecological conditions for invertebrate and vertebrate species' populations or communities on a larger spatial scale (Stevens \& Husband 1998, Fahring 2003, Cantrell et al. 2013, Graham-Sauvé et al. 2013, Batáry et al. 2014). However, any forest management also changes conditions on the microhabitat scale. This is typically represented by reduced vegetation heterogeneity and change in the amount of dead wood (Christensen et al. 2005). As a reaction to such regional or local scale changes, animals may modify their behaviour and habitat preferences (Telleria \& Santos 1995, Koprowski 2005, Suchomel et al. 2009).

Despite the fact that there is a relatively long tradition of forestry research in European countries, there is still a lack of detailed information on the many environmental impacts of certain management practices on biota. Some changes in microhabitat occur even when close-to-nature forest management is applied (Larsen 2012) and their influence on forest biodiversity is often invisible and thus ignored by forest managers. In order to determine the magnitude of different factors, organisms highly sensitive to such impacts should be considered. Owing to their rapid life cycle, a relatively high dominance in the forest ecosystem and a good dispersal ability, small terrestrial mammals are able to respond to habitat changes markedly and immediately (Sullivan et al. 2013). These features make the small mammals useful bio-indicators of the effects of sustainable forest management (Kaminski et al. 2007, Pearce \& Venier 2005, Klenner \& Sullivan 2009). The small mammals represent an important assemblage of species in temperate forests where they occupy mainly the forest floor (Manning \& Edge 2004). They are important phytophages and thus may significantly influence plant communities (Fuller et al. 2004). Therefore, understanding the habitat use and preferences of these species is essential for effective conservation and management strategies (Buesching et al. 2008) as well as for the implementation of sustainable forest management principles (Šporšić 2012). For that purpose, it is recommended to make comparison between commercially logged forests managed by close-to-nature practices and the natural forests having human activity excluded (Carey \& Johnson 1995).

In the temperate mixed forests of Central Europe, the yellow-necked mouse, Apodemus flavicollis (Melchior, 1834), and the bank vole, Clethrionomys glareolus (Schreber 1780), are often the dominant micromammal species that occur in all forest types of various ages. However, their distribution is not even, depending on several microhabitat parameters. There are many studies focusing on microhabitat preferences of the yellow-necked mouse and the bank vole (e.g. Pucek 1983, Mazurkiewicz \& Rajska-Jurgiel 1987, Canova 1993, Chetnicki \& Mazurkiewicz 1994, Miklós \& Žiak 2002, Buesching et al. 2008, Hille \& Mortelliti 2010, Suchomel et al. 2014). Summarising current knowledge, both species are considered forest generalists, however, the bank vole seems to be more selective in habitat use than the yellow-necked mouse. Regarding their microhabitat, the bank vole relies especially on dense undergrowth (Pucek 1983, Mazurkiewicz \& Rajska-Jurgiel 1987, Chetnicki \& Mazurkiewicz 1994, Miklós \& Žiak 2002, Hlôška \& Saniga 2005, Buesching et al. 2008, Lešo et al. 2014, Suchomel et al. 2014), where it feeds mainly on forbs and forbs-like vegeta- 
tion, tree leaves, large tree seeds and fungi (Hansson 1985). On the other hand, the yellow-necked mouse inhabits forest stands of various ages (Montgomery 1978, Gurnell et al. 1992, Marsh \& Harris 2000, Miklós \& Žiak 2002, Vukićević-Radić et al. 2006, Suchomel et al. 2014). However, the better seed availability may be a reason for preference of older forests in this granivorous species (Holišová \& Obrtel 1980, Heroldová 1994, Marsh \& Harris 2000). Considering that, the spatial distribution of these two small rodents may even differ on a local scale of a stand depending on management conditions. Thus, they also appear to be suitable species for analysis of management impacts of low magnitude which are expected in close-to-nature managed forests (e.g. shelterwood silvicultural system).

The paper aims to answer the question whether there exist differences in microhabitat preferences of these two dominant forest rodent species between the close-to-nature managed forest in the phase of stand regeneration (successive cutting of the parent trees in narrow strips of woodland when natural regeneration occurs) and the natural forest (pristine stand without a direct human influence and where natural processes are maintained) within similar climatic characteristics.

\section{Material and methods}

\section{Study area}

Two forest stands were selected for this study, with the same climatic conditions, similar tree species composition, but subjected to different management. The study plots were situated in the Kremnické vrchy Mts. which belong to the Western Carpathians (central Slovakia, N48 40', E1901', 850 m a.s.1.). Mixed Carpathian fir-beech forests (so-called Abieto-Fagetum) dominated in the study area. The first plot (hereafter 'unmanaged forest') was situated in the Mláčik National Nature Re- serve preserving natural fir-beech forest. The forest stand was composed of fir, Abies alba (40\%), spruce, Picea abies (30\%), European ash, Fraxinus excelsior (20\%), beech, Fagus sylvatica (5\%), and sycamore, Acer pseudoplatanus (5\%). The shrub layer was heterogeneously developed, being composed mainly of natural regeneration of the parent stand. The composition and density of herbaceous vegetation varied, depending on canopy cover. The second plot (hereafter 'managed forest') was situated in the commercial fir-beech forest where close-to-nature logging practices (shelterwood system) have been applied. The mature (110 years old) fir-beech stand dominated in two thirds of the plot area and was composed of beech (36\%), fir (34\%), European ash (20\%), sycamore (8\%) and Scots elm, Ulmus glabra (2\%). The shrub layer was poorly developed, being composed of natural regeneration of the parent stand. The composition and density of herbaceous vegetation was varied depending on the canopy cover. The remaining one third of the plot was composed of a clearing with 1-2 $\mathrm{m}$ tall dense young stand (beech 30\%, European elm 25\%, fir 10\%, and sycamore $10 \%$ ) with a high proportion of $R u$ bus sp. in undergrowth and herbal cover. The distance between the nearest edges of the two study plots was $150 \mathrm{~m}$.

\section{Trapping of rodents}

Small mammals were trapped during two vegetation periods in 2006 and 2007. Four trapping sessions were carried out each year, being equally distributed from the middle of April to the end of October. Each session lasted 72 h (i.e., three days and three nights). Trapping was conducted under favourable weather conditions to minimize trap mortality and pick a higher activity of rodents (Wróbel \& Bogdziewicz 2015). A square trapping grid of 100 points $(10 \times 10 \mathrm{~m}$ spacing) was established in each study plot (Fig. 1). One wooden box live trap (type Chmela) was placed at each trap- 


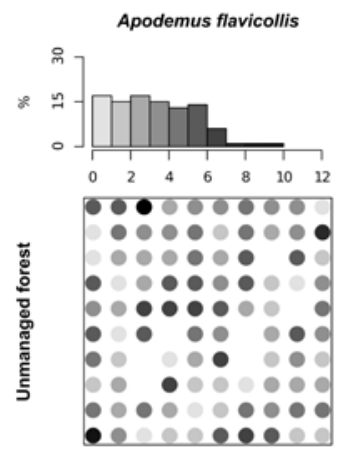

Clethrionomys glareolus
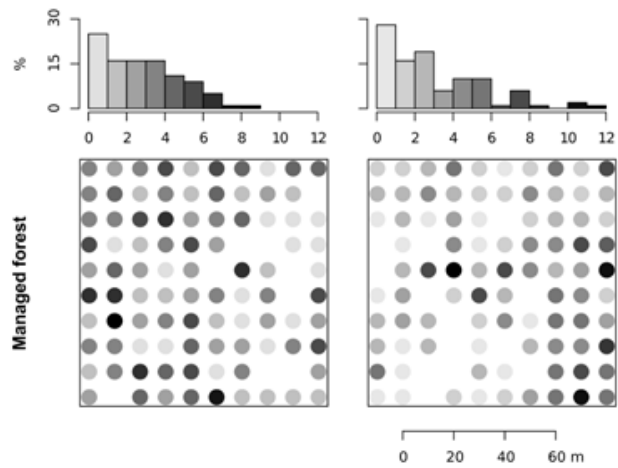

Figure 1

Frequency of species records of the yellow-necked wood mouse (Apodemus flavicollis) and the bank vole (Clethrionomys glareolus) in live traps during eight trapping sessions (four in each 2006 and 2007 from mid-April to late October) at two study plots of fixed trapping grid (100 traps, $10 \times 10 \mathrm{~m}$ ). The study plots were placed in mature (100-150 years old) fir-beech forest (Kremnické vrchy Mts., Slovakia) where part of the nature reserve represented an unmanaged forest whereas commercially logged part with the small-area shelterwood system represented a managed forest. Histograms summarize frequency of records for each plot and species.

ping point regardless of the microhabitat conditions. Each trap was provided with a small roof made of the tar paper to protect it against the rain. In cold weather, each trap was provided with a cotton bedding. Traps were baited with dry cat food granules and a slice of carrot providing some hydration during hot summer days. Traps were checked two times a day, at sunrise and at sunset. In order to evaluate mi- crohabitat preferences at the species level, the number of individual captures for both species at each point was recorded and data from both years were considered together. Thus an effect of individual preferences or movement was not considered for this purpose here.

\section{Data analysis}

We attempted to cover all potentially important factors influencing the spatial distribution of small mammals and possible interpretation of their effects. We measured ten microhabitat variables (Table 1) at each trapping point (radius of $5 \mathrm{~m}$ around the trap). Only trees with a diameter at breast-height of above $10 \mathrm{~cm}$ were considered as a 'tree' and similarly, fallen logs with such diameter were considered as 'woody debris'. Lying logs and branches thinner than $10 \mathrm{~cm}$ were considered as brushwood. The woody debris volume at each trapping point was calculated by multiplication of the average circle base of logs and their overall length (volume of cylinder). Vegetation up to $0.5 \mathrm{~m}$ of height was considered as 'herbs', from 0.5 to $1.5 \mathrm{~m}$ as 'undergrowth'. Coverage of herbs, undergrowth and brushwood was estimated subjectively by the same person.

The number of species records at each trapping point (dependent variable) was modelled using the Generalised Linear Models (GLM) with quasi-Poisson errors and the log-link function. For the factors extraction from the set of measured microhabitat variables the Principal Component Analysis (PCA) was used. Prior to the PCA, the data were standardised by subtracting the mean and divided by the standard deviation. The variables with factor loadings $|>0.4|$ were considered to be important. The factor scores of two first principal components (PC1 and PC2) were accepted as sources of variation including their interaction in the GLM (Table 1). Full-models for each species and study plot were fitted separately. Fits of such four models (percentage of the variation explained) were estimated through the calculation of explained deviance as follows, (null 
Table 1 Factor loadings of two first principal components (PC1 and PC2) extracted by the Principal Component Analysis. Important loadings are bold printed.

\begin{tabular}{lccrr}
\hline \multirow{2}{*}{ Variable } & \multicolumn{2}{c}{ Unmanaged forest } & \multicolumn{2}{c}{ Managed forest } \\
& PC1 & PC2 & \multicolumn{1}{c}{ PC1 } & PC2 \\
\hline The distance to the nearest tree $(\mathrm{m})$ & 0.315 & 0.296 & $\mathbf{0 . 4 3 2}$ & 0.158 \\
Breast-height diameter of the nearest tree $(\mathrm{m})$ & 0.338 & 0.263 & -0.312 & -0.138 \\
Distance to the nearest woody debris (m) & 0.288 & $\mathbf{- 0 . 4 2 7}$ & 0.315 & $\mathbf{- 0 . 5 7 2}$ \\
Woody debris volume $\left(\mathrm{m}^{2}\right)$ & -0.307 & 0.369 & -0.138 & 0.276 \\
Distance to the nearest stump (m) & 0.357 & -0.217 & 0.330 & $\mathbf{- 0 . 5 0 5}$ \\
Distance to the nearest root plate (m) & 0.311 & -0.171 & 0.000 & 0.242 \\
Herbal coverage $(\%)$ & $\mathbf{0 . 4 3 8}$ & 0.175 & $\mathbf{0 . 4 1 7}$ & 0.225 \\
Undergrowth coverage $(\%)$ & -0.000 & $\mathbf{0 . 4 3 2}$ & 0.368 & 0.184 \\
Brushwood coverage $(\%)$ & -0.273 & 0.250 & -0.198 & 0.175 \\
Number of trees $(\mathrm{n})$ & -0.334 & $\mathbf{- 0 . 4 1 1}$ & -0.368 & -0.351 \\
\hline Proportion of variance & 0.271 & 0.168 & 0.392 & 0.136 \\
\hline
\end{tabular}

deviance - residual deviance) / null deviance $\times$ 100. All computations and plot drawings were performed in the $\mathrm{R}$ 3.2.0 software environment ( $\mathrm{R}$ Core Team 2015) using $\mathrm{R}$ packages 'MASS' (Ripley et al. 2015) and 'effects' (Fox et al. 2015).

\section{Results}

During two seasons of the study, 369 capture records of the yellow-necked mouse and 381 of the bank vole were collected altogether within the plot of unmanaged forest. In the same period, 321 captures of the yellow-necked mouse and 336 of the bank vole were recorded within the plot of managed forest. The number of species records at trapping points ranged from zero to ten for the yellow-necked mouse and from zero to twelve for the bank vole. Although the overall trapping frequency of the selected two rodent species was roughly equal, the frequency of records was more left-skewed in the plot managed by the shelter wood silvicultural system and in the bank vole. In the managed forest this species had a non-equal spatial distribution with a local concentration at some spots avoiding most of the plot area
(Fig. 1).

The herbal coverage (PC1) and the distance to the nearest woody debris (PC2) were the most important measured microhabitat variables which may explain the occurrence of the two rodent species in the study plots (important loadings in both managed and unmanaged forest, Table 1). Inspecting results of the GLM (Fig. 2, Table 2) a significant effect of the PC2 in the unmanaged forest $(\mathrm{p}<0.05)$ was found. The number of records in both species increased with a decreasing number of trees, increasing undergrowth coverage and the decreasing distance to the nearest woody debris. On the other hand, in the managed forest, the pattern was different. An increasing distance to the nearest tree and increasing herbal coverage (PC1) had a negative effect on the yellow-necked mouse, while in contrast, the increase in values of the same variables shows an increase in the bank vole occurrence. Moreover, the number of records of the bank vole increased with the reducing distance to the nearest woody debris and to the nearest stump (PC2). Goodness-of-fit of our models to the observed data ranged markedly from $6.6 \%$ to $32.9 \%$. Microhabitat variables used in the GLM explained most of variation (the best fit 

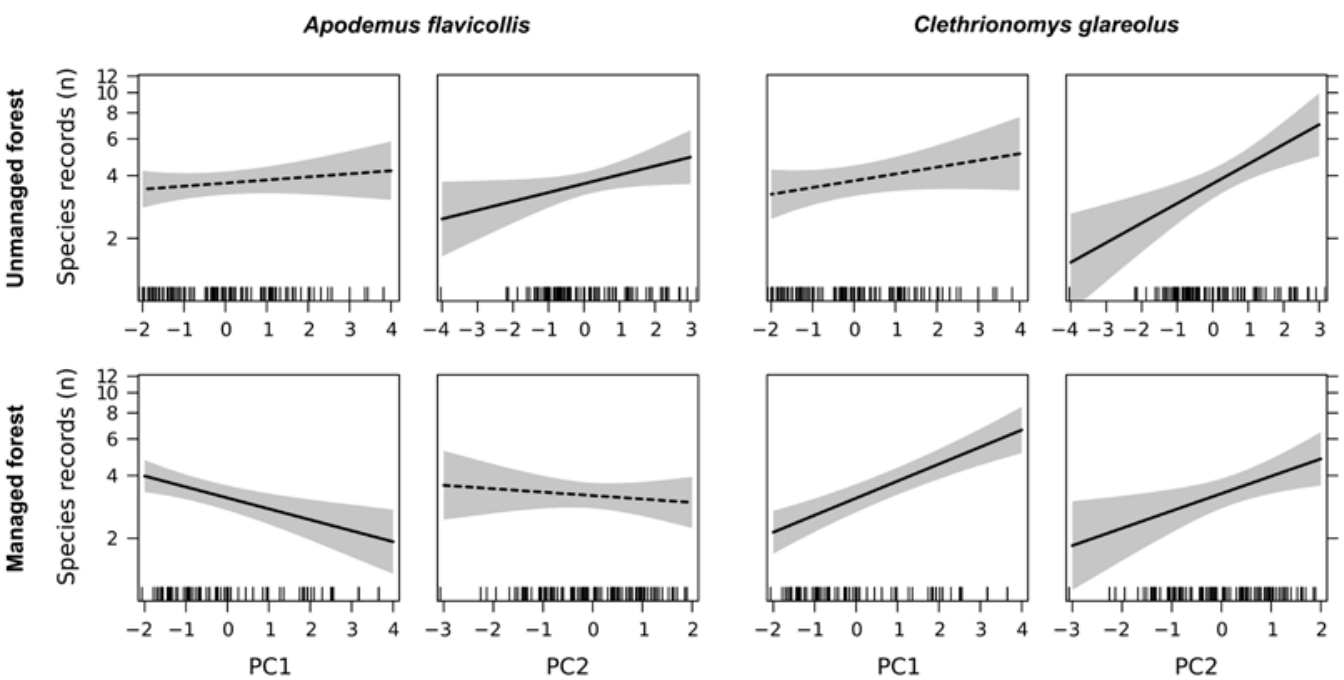

Figure 2 Relationships between numbers of species records and habitat characteristics. Lines show fitted values (with 95\% confidence intervals) of Generalized Linear Models for main effects only (PC1 and PC2). Significant effects $(\mathrm{p}<0.05)$ are shown by solid lines, non-significant by dashed lines. For habitat characteristics associated with PC components see Table 1.

Table 2 Results of Generalized Linear Models of habitat preferences by the yellow-necked wood mouse (Apodemus flavicollis) and the bank vole (Clethrionomys glareolus). The number of species records was used as a response variable. For microhabitat characteristics associated with PC components (explanatory variables) used in particular models see Table 1.

\begin{tabular}{|c|c|c|c|c|c|}
\hline Plot / Species & Term & Estimate & $S E$ & $t$ & $p$ \\
\hline \multicolumn{6}{|l|}{ Unmanaged forest } \\
\hline \multirow[t]{4}{*}{ Apodemus flavicollis } & $\mathrm{PC} 1$ & 0.05 & 0.04 & 1.46 & 0.147 \\
\hline & $\mathrm{PC} 2$ & 0.09 & 0.04 & 2.03 & 0.045 \\
\hline & $\mathrm{PC} 1 \times \mathrm{PC} 2$ & 0.03 & 0.02 & 1.44 & 0.154 \\
\hline & & & & \multicolumn{2}{|c|}{$($ Explained deviance $=6.6 \%)$} \\
\hline \multirow{4}{*}{ Clethrionomys glareolus } & $\mathrm{PC} 1$ & 0.07 & 0.05 & 1.35 & 0.180 \\
\hline & $\mathrm{PC} 2$ & 0.22 & 0.06 & 3.88 & 0.000 \\
\hline & $\mathrm{PC} 1 \times \mathrm{PC} 2$ & -0.00 & 0.03 & -0.17 & 0.868 \\
\hline & & & & \multicolumn{2}{|c|}{$($ Explained deviance $=14.1 \%)$} \\
\hline \multicolumn{6}{|l|}{ Managed forest } \\
\hline \multirow[t]{4}{*}{ Apodemus flavicollis } & $\mathrm{PC} 1$ & -0.16 & 0.04 & -4.19 & 0.000 \\
\hline & $\mathrm{PC} 2$ & -0.02 & 0.06 & -0.33 & 0.744 \\
\hline & $\mathrm{PC} 1 \times \mathrm{PC} 2$ & -0.08 & 0.03 & -2.41 & 0.018 \\
\hline & & & & \multicolumn{2}{|c|}{$($ Explained deviance $=15.4 \%)$} \\
\hline \multirow[t]{4}{*}{ Clethrionomys glareolus } & $\mathrm{PC} 1$ & 0.19 & 0.04 & 5.39 & 0.000 \\
\hline & $\mathrm{PC} 2$ & 0.25 & 0.08 & 3.27 & 0.002 \\
\hline & $\mathrm{PC} 1 \times \mathrm{PC} 2$ & -0.03 & 0.04 & -0.93 & 0.356 \\
\hline & & & & \multicolumn{2}{|c|}{$($ Explained deviance $=32.9 \%)$} \\
\hline
\end{tabular}


model) in the more specialised species (bank vole) in the managed forest. In general, the percentage values indicating goodness-of-fit had doubled in both species when occurred in the managed forest (Table 2).

\section{Discussion}

Sustainable forest management, including shelter wood logging systems, is considered to have a low level of detrimental effects on biota (Ferguson 1996). In accordance with that, no significant differences were found in trapping frequencies of selected two dominant rodent species between the tested plots. The study clearly demonstrated that the species modify their spatial activity when comparing natural conditions with the close-to-nature managed forest. Vegetation cover and dead wood were found to be significant environmental factors affecting spatial distribution of both rodents. A larger effect of these variables and a smaller proportion of unexplained variation were observed in the managed forest. Besides, the managed forest conditions had influenced patterns in species preferences. A greater heterogeneity of environmental variables was found in the managed forest where silvicultural practices rapidly modify microhabitat structure.

In the unmanaged forest both species had similar microhabitat preferences and they occurred mostly at sites with the well-developed undergrowth coverage and the close distance to dead wood. They are mainly old natural forests that possess such conditions (Saniga \& Schütz 2001) and abundant rodent species can find a better food availability and good shelters there (e.g. Montgomery 1978, Gurnell et al. 1992, Chetnicki \& Mazurkiewicz 1994, Marsh \& Harris 2000, Buesching et al. 2008). However, a different situation was found in the plot located in the managed forest despite its similar age and tree species composition of the matured stands. In contrast to the bank vole, the yellow-necked mouse avoided sites of dense herbal vegetation (larger canopy gaps). This could be related to its feeding close to fruiting trees with seed crop (Castien \& Gosalbez 1994, Juškaitis 2002). On the other hand, the dead wood shortage in the managed plot attracted the bank vole to a limited number of sites. This finding is in agreement with the positive relationship between the decay stage and the number of southern red-backed voles (Myodes gapperi) that were detected in the areas where decaying woody debris was rare (Bowman et al. 2000). Several studies ascertained a positive relationship between abundance of small terrestrial mammals and the presence, distribution, amount and structure of dead wood on the microhabitat scale (Carey \& Johnson 1995, Bowman et al. 2000, Buts \& McComb 2000, Manning \& Edge 2004). Presence and overall volume of dead wood seems to be the most significant difference between compared forest plots. The mean volume of dead trees (standing and lying) in the tested unmanaged plot was approximately 75 $\mathrm{m}^{3} \cdot \mathrm{ha}^{-1}$, with the portion of lying stems of $66 \%$ (Vencúrik et al. 2012). Within the managed forest, lying stems were practically absent and the dead wood consisted mainly of brushwood heaps and stumps retained after harvesting.

We suppose that different responses of rodent species to the environmental factors in the managed forest can be thus related to a higher spatial variation of measured variables (especially the dead wood) in the plot where the shelterwood system of forest management is applied. In Central Europe, the shelterwood system is the most common method applied for long-term natural regeneration of forest stands (Peterken 1993, Barna et al. 2010). The findings about specific responses to microhabitat changes in this paper can support silvicultural decisions that balance the close-to-nature forest management and biodiversity conservation (Šporšić 2012). The effects of coarse woody debris on the abundance of small mammals have received increasing attention over the last decade, especially in the context of new silvi- 
cultural practices proposing to stop dwindling stock of woody debris in managed forests (Fauteux et al. 2012). However, it is suggested that even in close-to-nature forest management, preserving stumps and brushwood heaps (harvest remains) can have a beneficial effect for biota. In order to fulfil the requirements of a large spectrum of wood-depending organisms, it is important to preserve not only larger amounts of dead wood, but also dead wood of different types and dimensions, and to secure a long-term continuity of dead wood (Christensen et al. 2005).

\section{Conclusion}

Small terrestrial mammals are often studied by ecologists in relation to forest management influence on animals. There are two main reasons to choose this animal group for such research. Owing to special characteristics, they are suitable bioindicators of habitat quality changes, some of them are important forest phytophages with a serious impact on forest tree regeneration. To answer the question whether close-to-nature forest management can cause differences in microhabitat preferences of small terrestrial mammals, two dominant forest rodent species were studied in the unmanaged and managed forest stands whereas other habitat and climatic characteristics remained similar. The shelterwood logging system, which belongs to close-to-nature forestry practices, is considered to be one of the least detrimental silvicultural systems, meeting the requirements of sustainable forest management. It expects a low level of possible detrimental effects on biota. Congruently with that we did not find significant differences in trapping frequencies of the two dominant rodent species between managed and unmanaged forests. Despite the similar quantity of both species in the studied plots, our results clearly demonstrated that the species altered their microhabitat preferences when comparing natural conditions with the close-to-naturally 266 managed forest. While both the yellow-necked mouse and the bank vole preferred the open tree canopy conditioning the well-developed undergrowth coverage in the natural forest, their microhabitat preferences differed in the managed forest. The yellow-necked mouse avoided deforested parts of the study plot in the managed forest, in contrary to the bank vole which preferred clearing with dense undergrowth there. Apart from vegetation cover also dead wood was found as a significant environmental factor positively affecting spatial distribution of the both rodents.

\section{Acknowledgements}

This contribution is the result of the projects implementation: "Centre of Excellence: Adaptive Forest Ecosystems" (ITMS 26220120006) and "Completing the Centre of Excellence: adaptive Forest Ecosystems" (ITMS 26220120049) supported by the Operational Programme Research and Development within the European Regional Development Fund. This work was also supported by the Slovak Research and Development Agency under the contract No. APVV-14-0637. We thank to the Forestry School Enterprise of the Technical University in Zvolen for providing a field station, Pavel Gibas for his help in the field, Tereza Thompson and Jana Luptáková for revising English and anonymous reviewer for improving the manuscript.

\section{References}

Baker M.D., Lacki M.J., 1997. Short-term changes in bird communities in response to silvicultural prescriptions. Forest Ecology and Management 96: 27-36. DOI: 10.1016/S0378-1127(97)00052-2

Barna M., Sedmák R., Marušák R., 2010. Response of European beech radial growth to shelterwood cutting. Folia Oecologica 37: 125-136.

Batáry P., Fronczek S., Normann C., Scherber C., Tscharntke T., 2014: How do edge effect and tree species diversity change bird diversity and avian nest survival in Germany's largest deciduous forest? Forest Ecology 
and Management 319: 44-50. DOI: 10.1016/j.foreco.2014.02.004

Bowman J.C., Sleep D., Forbes G.J., Edwards M., 2000. The associations of small mammals with coarse woody debris at $\log$ and stand scales. Forest Ecology and Management 129: 119-124. DOI: 10.1016/S03781127(99)00152-8

Buesching C.D., Newman C., Twell R., Macdonald D.W., 2008. Reasons for arboreality in wood mice Apodemus sylvaticus and Bank voles Myodes glareolus. Mammalian Biology 73: 318-324. DOI: 10.1016/j.mambio.2007.09.009

Butts S.R., McComb W.C., 2000. Associations of forest-floor vertebrates with coarse woody debris in managed forests of western Oregon. Journal of Wildlife Management 64: 94-105. DOI: 10.2307/3802978

Canova L., 1993. Resource partitioning between the bank vole Clethrionomys glareolus and the wood mouse Apodemus sylvaticus in woodland habitats. Italian Journal of Zoology 60: 193-198.

Cantrell A.W., Wang Y., Schweitzer C.J., Greenberg C.H., 2013. Short term response of herpetofauna to oak regeneration treatments on the mid-Cumberland Plateau of southern Tennessee. Forest Ecology and Management 295: 239-247. DOI: 10.1016/j.foreco.2013.01.027

Carey A.B., Johnson M.L., 1995. Small mammals in managed, naturally young, and old-growth forests. Ecological Applications 5: 336-352. DOI: 10.2307/1942026

Castien E., Gosalbez J., 1994. Habitat selection of Apodemus flavicollis in a Fagus sylvatica forest in the Western Pyrenees. Folia Zoologica 43: 219-224.

Chetnicki W., Mazurkiewicz M., 1994. Dispersion of the bank vole in fine- and coarse-grained mosaics of deciduous and mixed coniferous forests. Acta Theriologica 39: 127-142. DOI: 10.4098/AT.arch.94-17

Christensen M., Hahn K., Mountford E.P., Ódor P., Standovár T., Rozenbergar D., Diaci J., Wijdeven S., Meyer P., Winter S., Vrska T., 2005. Dead wood in European beech (Fagus sylvatica) forest reserves. Forest Ecology and Management 210: 267-282. DOI: 10.1016/j.foreco.2005.02.032

Ecke F., Lofgren O., Sorlin D., 2002. Population dynamics of small mammals in relation to forest age and structural habitat factors in northern Sweden. Journal of Applied Ecology 39: 781-792. DOI: 10.1046/j.13652664.2002.00759.x

Fahring L., 2003. Effects of habitat fragmentation on biodiversity. Annual Review of Ecology, Evolution, and Systematics 34: 487-515. DOI: 10.1146/annurev.ecolsys.34.011802.132419

Fauteux D., Imbeau L., Drapeau P., Mazerolle M.J., 2012. Small mammal responses to coarse woody debris distribution at different spatial scales in managed and unmanaged boreal forests. Forest Ecology and Management 266: 194-205. DOI: 10.1016/j.foreco.2011.11.020

Ferguson I.S., 1996. Sustainable Forest Management. Oxford University Press, Melbourne, $162 \mathrm{p}$.

Fox J., Weisberg S., Friendly M., Hong J., Andersen R
Firth D., Taylor S., 2015. effects: Effect displays for linear, generalized linear, and other models. $\mathrm{R}$ package version 3.0-0. http://cran.r-project.org/package=effects

Fuller R.J., Warren M.S., 1991. Conservation management in ancient and modern woodlands: responses of fauna to edges and rotations. In Spellerberg I.F., Goldsmith F.B., Morris M.G. (eds.), The scientific management of temperate communities for conservation. British Ecological Society, 31st Symposium, Blackwell Scientific Publicaitons, Oxford, pp. 445-471.

Fuller A.K., Harrison D.J., Lachowski H.J., 2004. Stand scale effects of partial harvesting and clearcutting on small mammals and forest structure. Forest Ecology and Management 191: 373-386. DOI: 10.1016/j.foreco.2004.01.014

Graham-Suavé L., Work T.T., Kneeshaw D., Messier C., 2013. Shelterwood and multicohort management have similar initial effects on ground beetle assemblages in boreal forests. Forest Ecology and Management 306: 266-274. DOI: 10.1016/j.foreco.2013.06.019

Gurnell J., Hicks M., Whitbread S., 1992. The effects of coppice management on small mammal populations. In Buckley G.P. (ed.), Ecology and management of coppice woodlands. Chapman and Hall, London, pp. 213232. DOI: 10.1007/978-94-011-2362-4_11

Hansson L., 1985. Clethrionomys food: generic, specific and regional characteristics. Annales Zoologici Fennici 22: 315-318.

Heroldová M., 1994. Diet of four rodent species from Robinia pseudoacacia stands in South Moravia. Acta Theriologica 39: 333-337. DOI: 10.4098/AT.arch.94-38

Hille S.M., Mortelliti A., 2010. Microhabitat partitioning of Apodemus flavicollis and Myodes glareolus in sub-montane Alps, a preliminary assessment. Hystrix Italian Journal of Mammalogy 21: 157-163.

Hlôška L., Saniga M., 2005. Community structure of small mammals (Insectivora, Rodentia) in the Kl'ačianska Magura National Nature Reserve (Malá Fatra Mts., Western Carpathians). Folia Oecologica 32: 59-67.

Holišová V., Obrtel R., 1980. Variation in the trophic niche of Apodemus flavicollis in two different habitats. Folia Zoologica 29: 33-41.

Juškaitis R., 2002. Spatial distribution of the yellow-necked mouse (Apodemus flavicollis) in large forest areas and its relation with seed crop of forest trees. Mammalian Biology 67: 206-211. DOI: 10.1078/16165047-00031

Kaminski J.A., Davis M., Kelly M., Keyser P.D., 2007. Disturbance effects on small mammal species in a managed Appalachian forest. American Midland Naturalist 157: 385-397. DOI: 10.1674/0003-0031(2007)157[385:DEOSMS]2.0. $\mathrm{CO} ; 2$

Klenner W., Sullivan T.P., 2009. Partial and clearcut harvesting of dry Douglas-fir forests: Implications for small mammal communities. Forest Ecology and Management 257: 1078-1086. DOI: $10.1016 /$ j.foreco.2008.11.012 
Koprowski J.L., 2005. The response of tree squirrels to fragmentation: a review and synthesis. Animal Conservation 8: 369-376. DOI: 10.1017/S1367943005002416

Larsen J.B., 2012. Close-to-nature forest management: The Danish approach to sustainable forestry. In Diez J.J. (ed.), Sustainable forest management - current research. InTech, pp. 200-218.

Lešo P., Lešová A., Kropil R., 2014. Influence of forest fragmentation on the distribution of small terrestrial mammals in fir-beech commercial forest. Journal of Forest Science 60: 324-329.

Manning J.A., Edge W.D., 2004. Small mammals survival and downed wood at multiple scales in managed forests. Journal of Mammalogy 85: 87-96. DOI: 10.1644/1545-1542(2004)085<0087:SMSADW>2.0. $\mathrm{CO} ; 2$

Marsh A.C.W., Harris S., 2000. Partitioning of wood - landhabitat resources by two sympatric species of Apodemus: lessons for the conservation of the yellownecked mouse (A. flavicollis) in Britain. Biological Conservation 92: 275-283. DOI: 10.1016/S00063207(99)00071-3

Mazurkiewicz M., Rajska-Jurgiel E., 1987. Numbers, species composition and residency of rodent community in forest and fiels-forest ecotones. Acta Theriologica 32: 413-432. DOI: 10.4098/AT.arch.87-29

Miklós P., Žiak D., 2002. Microhabitat selection by three small mammal species in oak-elm forest. Folia Zoologica 51: 275-288.

Montgomery W.I., 1978. Studies on the distributions of Apodemus sylvaticus (L.) and A. flavicollis (Melchior) in Britain. Mammal Review 8: 177-184. DOI: 10.1111/ j.1365-2907.1978.tb00226.x

Pearce J., Venier L., 2005. Small mammals as bioindicators of sustainable boreal forest management. Forest Ecology and Management 208: 153-175. DOI: 10.1016/j.foreco.2004.11.024

Perry R.W., Thill R.E., 2013. Long-term responses of disturbance-associated birds after different timber harvests. Forest Ecology and Management 307: 274-283. DOI: 10.1016/j.foreco.2013.07.026

Peterken G.F., 1993. Woodland conservation and Management, second edition. Chapman and Hall, London, $374 \mathrm{p}$.

Pucek M., 1983. Habitat preference. In Petrusewicz K. (ed.), Ecology of bank vole. Acta Theriologica 28 suppl. 1, pp. 31-40. DOI: 10.4098/at.arch.83-47

R Core Team, 2015. R: A language and Environment for Statistical Computing. R Foundation for Statistical Computing, Vienna. http://www.R-project.org
Ripley B., Venables B., Bates D.M., Hornik K., Gebhardt A., Firth D., 2015. MASS: Support functions and datasets for Venables and Ripley's MASS. R package version 7.3-45. http://cran.r-project.org/package=MASS

Saniga M., Schütz J.P., 2001. Dynamics of changes in dead wood share in selected beech virgin forests in Slovakia within their development cycle. Journal of Forest Science 47: 557-565.

Stevens S.M., Husband T.P., 1998. The influence of edge on small mammals: evidence from Brazilian Atlantic forest fragments. Biological Conservation 85: 1-8. DOI: 10.1016/S0006-3207(98)00003-2

Suchomel J., Krojerová-Prokešová J., Heroldová M., Purchart L., Barančeková M., Homolka M., 2009. Habitat preferences of small terrestrial mammals in the mountain forest clearings. Beskydy 2: 195-200.

Suchomel J., Purchart L., Čepelka L., Heroldová M., 2014. Structure and diversity of small mammal communities of mountain forests in Western Carpathians. European Journal of Forest Research 133: 481-490. DOI: $10.1007 /$ s10342-013-0778-y

Sullivan T.P., Sullivan D.S., Lindgren P.M.F., Ransome D.B., 2013. Stand structure and small mammals in intensively managed forests: Scale, time, and testing extremes. Forest Ecology and Management 310: 10711087. DOI: $10.1016 /$ j.foreco.2013.02.025

Šporčić M., 2012. Application of multi-criteria methods in natural resource management - a focus on forestry. In Diez J.J. (ed.), Sustainable forest management - current research. InTech, pp, 406-430.

Telleria J.L., Santos T., 1995. Effects of forest fragmentation on a guild of wintering passerines: the role of habitat selection. Biological Conservation 71: 61-67. DOI: 10.1016/0006-3207(94)00021-H

Vencúrik J., Kucbel S., Jaloviar P., 2012. Types of forest stand structures and analysis of natural regeneration in mixed forest of National nature reserve Mláčik (Central Slovakia). Zprávy lesnického výzkumu 57(2): 93100.

Vukićević-Radić O., Matić R., Kataranovski D., Stamenković S., 2006. Spatial organization and home range of Apodemus flavicollis and A. agrarius on Mt. Avala, Serbia. Acta Zoologica Academiae Scientiarum Hungaricae 52:81-96.

Wróbel A., Bogdziewicz M., 2015. It is raining mice and voles: which weather conditions influence the activity of Apodemus flavicollis and Myodes glareolus? European Journal of Wildlife Research 61: 475-478. DOI: 10.1007/s10344-014-0892-2 